\title{
A Cross-sectional Analysis of the Impact of COVID- 19 Related Stressors on Canadian University Students' Mental Health and Wellbeing
}

Brooke Linden ( $\sim$ brooke.linden@queensu.ca )

Queen's University

Caitlin Monaghan

University of Toronto

Sally Zheng

Ryerson University

Jake Rose

McGill University

Alyson Mahar

University of Manitoba

\section{Research Article}

Keywords: mental health, COVID-19, pandemic, stress, postsecondary, higher education

Posted Date: October 25th, 2021

DOI: https://doi.org/10.21203/rs.3.rs-971271/v1

License: (c) (i) This work is licensed under a Creative Commons Attribution 4.0 International License.

Read Full License 


\section{Abstract}

\section{Background}

National, cross-sectional data suggests that over one third of young, post-secondary aged adults are endorsing moderate to severe levels of anxiety and depression in the wake of the COVID-19 pandemic. The purpose of this study was to evaluate the impact of pandemic-related stressors on university students' levels of psychological distress, using a large sample of students attending schools across Canada.

\section{Methods}

This study analyzed the first data time point of a cross-sectional, repeated measures study of university student stress completed during the 2020-2021 academic year. Participants ( $n=4954)$ were students attending fourteen universities across Canada. Participants completed an online survey that included questions about demographics, stress, COVID-19 diagnosis history, psychological distress, history of mental illness, and resilience.

\section{Results}

Participants reported the highest mean severity of stress ratings for the following COVID-19 related stressors: the pandemic's effect on academics $(X=2.76, S D=1.06)$ and uncertainty around how long the pandemic will last $(X=2.68, S D=0.95)$. Average psychological distress score was high in this sample ( $X=$ $28.67, S D=9.53$ ) with nearly half the sample scoring in the 'severe distress' category. Modified log poisson regression models were stratified by high/low resiliency. Within the low resilience stratum, the strongest associations were observed for: COVID-19's effect on academics (RR=1.14 [95\% $\mathrm{Cl} 1.08,1.20])$; difficulties accessing health care during the pandemic ( $R R=1.12$ [95\% $\mathrm{Cl} 1.07,1.18])$; and loneliness as a result of quarantine/self-isolation $(R=1.11[95 \% \mathrm{Cl} 1.06,1.16])$. Within the high resilience stratum, the strongest associations were observed for: COVID-19's effect on academics ( $R R=1.32$ [95\% Cl 1.25, 1.41]); difficulties accessing healthcare during the pandemic ( $\mathrm{RR}=1.25[95 \% \mathrm{Cl} 1.18,1.33]))$; and uncertainty around how long the pandemic will last $(R R=1.24[95 \% \mathrm{Cl} 1.16,1.32])$. Notably, larger effects were observed for those in the high resilience stratum, contrary to expectations.

\section{Conclusions}

The results of this study suggest that students' psychological distress has been significantly impacted by the COVID-19 pandemic. In order to effectively support students' wellbeing throughout the pandemic and beyond, improved understanding of stress related to COVID-19 is needed. Implications of this study and areas for future research are discussed.

\section{Background}


The global COVID-19 pandemic has introduced a number of novel challenges (e.g., diminished access to mental health services and social support systems), exacerbating pre-existing mental health concerns among the Canadian population. Research has demonstrated the presence of collective anxiety, increased household conflict, social isolation, economic downturn, and job loss or insecurity related to the spread of the virus (1). National cross-sectional data suggest the proportion of people accessing face-toface mental health services has drastically decreased since the onset of the pandemic, while levels of self-reported anxiety and depression have increased (1). Young, post-secondary aged adults appear to be the most severely impacted, with about one third endorsing moderate to severe levels of anxiety $(1,2)$.

A group already at high risk for chronic stress and the development of mental health issues, postsecondary students have experienced unexpected disruptions to their education as a result of the pandemic, including: a mandatory transition to online learning, isolation and loneliness resulting from campus closures, anxiety about meeting educational milestones and securing employment following graduation, and financial strain $(3,4)$. One survey of over 100,000 Canadian university students indicated that $35 \%$ had work placements delayed or cancelled, $11 \%$ were not able to complete credentials as planned, and most were "very" or "extremely" concerned about finances (68\%), job prospects (67\%), and grades (63\%) (5). These novel pandemic-related stressors join the ranks of a number of pre-existing stressors faced by students within the post-secondary setting (6-9), well-poised to produce psychological distress, particularly among those with lower levels of resilience. Resilience (i.e., the individual ability to adapt to significant stress and adversity (10)) is a well-established effect modifier of the relationship between stress and the development of mental health issues, with those demonstrating higher levels of resilience better able to cope with stressful situations. Conversely, individuals demonstrating lower levels of resilience are often more negatively affected by stressful situations and more likely to engage in less constructive, maladaptive methods of coping, such as avoidance or distraction (11). Preliminary evidence suggests that stress and isolation associated with the pandemic have contributed to an increase in psychological distress (i.e., anxiety, depression) and the use of maladaptive coping methods (i.e., substance misuse, poor eating patterns) among this population $(12,13)$.

The addition of new stressors related to the pandemic is of particular concern given that increasing demand for campus mental health services over the past several years has already surpassed institutional capacities (14). Furthermore, as mental health concerns have escalated, access to supports and services has decreased, leaving post-secondary institutions with the challenge of providing supports to help sustain students' well-being $(1,13)$. Pandemic aside, students are at high risk for chronic stress and the development of mental health problems. Over two thirds of student respondents to the 2019 National College Health Assessment (NCHA II) survey ( $n=55284$ ) had felt "overwhelming anxiety" within the past twelve months, while over half had felt "so depressed that it was difficult to function" (7). Importantly, these prevalence estimates represent statistically significant increases since the 2013 iteration of the survey (15). Increases in both the prevalence and complexity of student mental health concerns has brought about widespread recognition of the need to better support student well-being; a challenge now intensified by the COVID-19 pandemic $(7,16)$. 


\section{Purpose of Study}

Although efforts to better understand student stress and predictors of mental health outcomes have increased in recent years, the pandemic has introduced significant novel challenges and interrupted access to existing mental health services on campus. In order to effectively support students' wellbeing throughout the prolonged pandemic, improved understanding of stress related to COVID-19 is needed. To date, few studies have examined the impact of the pandemic on the mental health of North American university students $(12,17)$, and even fewer have focused on Canadian students in particular $(18)$. The purpose of this study was to evaluate the impact of COVID-19 related stressors on university students' levels of psychological distress, using a large sample of students attending schools across Canada.

\section{Methods}

A cross-sectional, repeated measures study of university student stress and mental health outcomes was completed during the 2020-2021 academic year, with data on exposure and outcomes collected via online surveys in October, January, and March/April (19). This article focuses on the October time point, which coincided with the second wave of the pandemic. Survey questions included: demographics; stress; COVID-19 diagnosis history among family, friends, and self; psychological distress; history of mental illness; and resilience. Surveys remained open for approximately three weeks, with a reminder sent at the halfway point. Participants were students attending fourteen universities across Canada, representing nine provinces and one territory. Participants were asked to review a letter of information, and indicate their informed consent by responding to a prompt prior to accessing the survey. The sampling method and sample size used was at the discretion of each participating institution (see Appendix A). Ethics approval was obtained from Queen's University's Health Sciences and Affiliated Teaching Hospitals Research Ethics Board (\#6029173) as the lead university, as well as from an ethics board at each participating university.

\section{Measures}

\section{Demographics}

The survey collected the following demographic information on participants: age, sex, level of study (undergraduate, graduate, or professional program), international student status (yes/no), first generation student status (yes/no), and region of institution (Northern Canada, Atlantic Canada, Western Canada, or Central Canada). All demographic variables with the exception of age were categorical in nature. Due to small cell counts, the 14 participants from the Northern region of Canada were excluded from analyses.

\section{COVID-19 Related Stressors}

Survey items evaluating stressors related to the COVID-19 pandemic were selected from question banks developed by the American College Health Association and Healthy Minds Network (20) and Mental Health Research Canada (21). A total of 13 potential stressors were posed, with participants asked to 
indicate the level of stress experienced by each item. Response categories were scored on an adjectival scale ranging from 1 (not stressful) to 4 (extremely stressful). Participants could also respond 0 (N/A or Didn't Happen) in the event that a stressor did not apply to them or they did not experience it. As a result of time constraints associated with developing survey measures to evaluate the effects of COVID-19 among university students, these items have not yet been validated, but have been used in large crosssectional studies among post-secondary students $(20,21)$. Two separate, subsequent questions asked whether participants had a friend or family member who had contracted COVID-19, and if participants themselves had contracted the virus (yes/no/unsure). Due to small cell counts ( $<1 \%$ of sample), the latter were excluded from analyses.

\section{Mental Health Variables}

The Kessler Psychological Distress Scale (K10) 10-item version (22) and the Connor-Davidson Resiliency Scale (CD-RISC) 10-item version (23) were used to evaluate participants' level of psychological distress and resilience, respectively. Both measures have previously been used among samples of post-secondary students and have demonstrated strong psychometric properties. The CD-RISC has been shown to have excellent internal consistency $(a=0.86)(24)$, and has demonstrated evidence of construct validity in its significant relationships with like constructs, including the General Health Questionnaire (GHQ-12, $r=$ 0.45), the Academic Hardiness Scale (AHS, $r=0.42)$, the Stress Arousal Scale (SAS, $r=-0.31)$, and the Maslach Burnout Scale (MBS, $r=-0.38$ ) in one study (24) and the Perceived Stress Scale (PSS-10, $r=$ -0.49 ) and Kessler Psychological Distress Scale (K10, $r=-0.46)$ in another (25). The tool has also been validated for use among French-speaking Canadian students (26). Similarly, the K10 has demonstrated strong internal consistency reliability $(a=0.86)(27)$, in addition to evidence of construct validity through its significant relationships with the Perceived Stress Scale (PSS-10, $r=0.74)$, CD-RISC-10 $(r=-0.46)$, and Post-Secondary Student Stressors Index (PSSI, $r=0.52)(25)$.

In this study, continuous K10 scores ranging from 10-50 were dichotomized to identify positive screens for at least a "moderate mental disorder" according to recommended thresholds (28). Scores $\geq 25$ indicated positive screens. CD-RISC scores were left as continuous, with higher scores indicating a higher level of resilience (23). We hypothesized that level of resilience would be an effect modifier of the relationship between COVID-19 related stressors and positive screens for at least a moderate mental disorder. We a priori planned to stratify results at the sample mean, with the high resilience group reporting a score $>26$ and the low resilience group reporting a score $\leq 26$. Finally, participants were asked whether they had ever received a diagnosis for a mental illness from a healthcare provider (yes/no). This variable was included as a covariate in the analyses.

\section{Analysis}

Descriptive statistics were calculated for all variables. Because COVID-19 related stressors were moderately to highly intercorrelated, suggesting measurement of the same underlying construct, separate crude and adjusted models were run to estimate the association between each stressor and psychological distress. Adjusted models included age, sex, level of study, international student status, 
first generation student status, region of institution, friend/family member COVID-19 diagnosis, and personal diagnosed mental illness. Modified log poisson regression models were run to derive relative risks (RR) and associated 95\% confidence intervals (29).

\section{Missing Data}

Participants who indicated that a COVID-19 related stressor was not applicable or that it was not experienced (i.e., a response of zero) were not included in the analysis. A complete case analysis approach was taken to address missing data, where any participant who had complete information for the variables relevant to each model was included in the analysis. A supplementary table reporting the sample sizes for each model can be found in Appendix B.

\section{Results}

\section{Sample and Participants}

Table 1 presents the demographic characteristics of the sample ( $n=4954)$. The largest percentage of participants were female $(74.3 \%)$, between 18 and 20 years of age $(42.7 \%)$, and were studying at the undergraduate level $(78.2 \%)$. The average age was 23.4 years of age $(S D=6.9)$. About $12 \%$ of students in this sample were international students, and $27 \%$ identified as being first generation university students (the first in their immediate family to attend university). Our sample included students attending university in Atlantic, Central, and Western Canada. 
Table 1

Demographic Characteristics of Sample $(N=4954)$

\begin{tabular}{|c|c|c|}
\hline Variable & $\mathrm{n}$ & $\%$ \\
\hline \multicolumn{3}{|l|}{ Region of Institution } \\
\hline Atlantic Canada & 2014 & 40.8 \\
\hline Central Canada & 972 & 19.7 \\
\hline Western Canada & 1952 & 39.5 \\
\hline \multicolumn{3}{|l|}{ Sex } \\
\hline Male & 1240 & 25.7 \\
\hline Female & 3584 & 74.3 \\
\hline \multicolumn{3}{|l|}{ Age } \\
\hline $18-20$ years & 2116 & 42.7 \\
\hline 21-24 years & 1546 & 31.2 \\
\hline $25-29$ years & 635 & 12.8 \\
\hline $30+$ years & 654 & 13.2 \\
\hline \multicolumn{3}{|l|}{ Level of Study } \\
\hline Undergraduate & 3774 & 78.2 \\
\hline Graduate & 889 & 18.4 \\
\hline Professional Program & 166 & 3.4 \\
\hline \multicolumn{3}{|l|}{ Student Status } \\
\hline International & 585 & 11.8 \\
\hline Domestic & 4358 & 88.2 \\
\hline \multicolumn{3}{|l|}{ First Generation Status } \\
\hline Yes & 1330 & 27.0 \\
\hline No & 3595 & 73.0 \\
\hline
\end{tabular}

Univariate Analyses

Table 2 displays the descriptive statistics for variables related to COVID-19. Of the thirteen COVID-19 related stressors, the highest mean ratings were observed among uncertainty around the pandemic's 
effect on academics (i.e., having to enrol in mandatory online classes) ( $X=2.76, S D=1.06$ ) and uncertainty around how long the pandemic might last $(X=2.68, S D=0.95)$. Concerns around family members or friends contracting the virus, loneliness stemming from quarantine/self-isolation, and concerns about others not following safety protocols also appeared to be considerable sources of stress $(X=2.46-2.55)$. Students appeared to be least concerned about ensuring they themselves were effectively following safety 
Table 2

Descriptive Statistics for COVID-19 Related Stressors

\begin{tabular}{|c|c|c|c|c|c|c|}
\hline \multicolumn{3}{|l|}{ Variable } & \multicolumn{4}{|l|}{$n(\%)$} \\
\hline \multirow[t]{2}{*}{ COVID-19 Related Stressors } & 0 & 1 & 2 & 3 & 4 & \multirow{2}{*}{$\begin{array}{l}\text { Mean } \\
(S D)^{1}\end{array}$} \\
\hline & $\begin{array}{l}\text { N/A or } \\
\text { Didn't } \\
\text { happen }\end{array}$ & $\begin{array}{l}\text { Not } \\
\text { stressful }\end{array}$ & $\begin{array}{l}\text { Somewhat } \\
\text { Stressful }\end{array}$ & $\begin{array}{l}\text { Very } \\
\text { Stressful }\end{array}$ & $\begin{array}{l}\text { Extremely } \\
\text { stressful }\end{array}$ & \\
\hline $\begin{array}{l}\text { 1. Uncertainty around length } \\
\text { of pandemic }\end{array}$ & $58(1.2)$ & $\begin{array}{l}527 \\
(10.6)\end{array}$ & $\begin{array}{l}1680 \\
(33.9)\end{array}$ & $\begin{array}{l}1527 \\
(30.8)\end{array}$ & $\begin{array}{l}1161 \\
(23.4)\end{array}$ & $\begin{array}{l}2.68 \\
(0.95)\end{array}$ \\
\hline $\begin{array}{l}\text { 2. Loneliness as a result of } \\
\text { quarantine/self-isolation }\end{array}$ & $\begin{array}{l}425 \\
(8.6)\end{array}$ & $\begin{array}{l}1040 \\
(21.0)\end{array}$ & $\begin{array}{l}1335 \\
(27.0)\end{array}$ & $\begin{array}{l}1153 \\
(23.3)\end{array}$ & $\begin{array}{l}998 \\
(20.2)\end{array}$ & $\begin{array}{l}2.47 \\
(1.07)\end{array}$ \\
\hline $\begin{array}{l}\text { 3. Worrying a family } \\
\text { member/friend will contract } \\
\text { COVID- } 19\end{array}$ & $\begin{array}{l}160 \\
(3.2)\end{array}$ & $\begin{array}{l}852 \\
(17.2)\end{array}$ & $\begin{array}{l}1623 \\
(32.8)\end{array}$ & $\begin{array}{l}1154 \\
(23.3)\end{array}$ & $\begin{array}{l}1161 \\
(23.5)\end{array}$ & $\begin{array}{l}2.55 \\
(1.04)\end{array}$ \\
\hline $\begin{array}{l}\text { 4. Worrying that I will } \\
\text { contract COVID-19 }\end{array}$ & $\begin{array}{l}193 \\
(3.9)\end{array}$ & $\begin{array}{l}1778 \\
(35.9)\end{array}$ & $\begin{array}{l}1656 \\
(33.5)\end{array}$ & $\begin{array}{l}743 \\
(15.0)\end{array}$ & $\begin{array}{l}579 \\
(11.7)\end{array}$ & $\begin{array}{l}2.03 \\
(1.01)\end{array}$ \\
\hline $\begin{array}{l}\text { 5. Returning to school during } \\
\text { COVID-19 }\end{array}$ & $\begin{array}{l}623 \\
(12.6)\end{array}$ & $\begin{array}{l}1271 \\
(25.7)\end{array}$ & $\begin{array}{l}1467 \\
(29.7)\end{array}$ & $\begin{array}{l}890 \\
(18.0)\end{array}$ & $\begin{array}{l}696 \\
(14.1)\end{array}$ & $\begin{array}{l}2.23 \\
(1.04)\end{array}$ \\
\hline $\begin{array}{l}\text { 6. COVID-19's effect on my } \\
\text { employment/finances }\end{array}$ & $\begin{array}{l}515 \\
(10.4)\end{array}$ & $\begin{array}{l}1028 \\
(20.8)\end{array}$ & $\begin{array}{l}1421 \\
(28.7)\end{array}$ & $\begin{array}{l}983 \\
(19.9)\end{array}$ & $\begin{array}{l}1004 \\
(20.3)\end{array}$ & $\begin{array}{l}2.44 \\
(1.08)\end{array}$ \\
\hline $\begin{array}{l}\text { 7. Difficulties accessing } \\
\text { physical/mental health } \\
\text { career as a result of COVID- } \\
19\end{array}$ & $\begin{array}{l}822 \\
(16.6)\end{array}$ & $\begin{array}{l}1372 \\
(27.7)\end{array}$ & $\begin{array}{l}1333 \\
(26.9)\end{array}$ & $\begin{array}{l}753 \\
(15.2)\end{array}$ & $\begin{array}{l}669 \\
(13.5)\end{array}$ & $\begin{array}{l}2.17 \\
(1.06)\end{array}$ \\
\hline $\begin{array}{l}\text { 8. COVID-19's effect on your } \\
\text { living situation }\end{array}$ & $\begin{array}{l}852 \\
(17.2)\end{array}$ & $\begin{array}{l}1717 \\
(34.7)\end{array}$ & $\begin{array}{l}1214 \\
(24.5)\end{array}$ & $\begin{array}{l}636 \\
(12.9)\end{array}$ & $\begin{array}{l}527 \\
(10.7)\end{array}$ & $\begin{array}{l}1.99 \\
(1.04)\end{array}$ \\
\hline $\begin{array}{l}\text { 9. Ensuring I am effectively } \\
\text { following COVID-19 safety } \\
\text { protocols }\end{array}$ & $\begin{array}{l}123 \\
(2.5)\end{array}$ & $\begin{array}{l}1976 \\
(39.9)\end{array}$ & $\begin{array}{l}1834 \\
(37.1)\end{array}$ & $\begin{array}{l}668 \\
(13.5)\end{array}$ & $348(7.0)$ & $\begin{array}{l}1.87 \\
(0.91)\end{array}$ \\
\hline $\begin{array}{l}\text { 10. People around me not } \\
\text { effectively following COVID- } \\
19 \text { safety protocols }\end{array}$ & $\begin{array}{l}154 \\
(3.1)\end{array}$ & $\begin{array}{l}798 \\
(16.1)\end{array}$ & $\begin{array}{l}1620 \\
(32.7)\end{array}$ & $\begin{array}{l}1271 \\
(25.7)\end{array}$ & $\begin{array}{l}1104 \\
(22.3)\end{array}$ & $\begin{array}{l}2.56 \\
(1.02)\end{array}$ \\
\hline $\begin{array}{l}\text { 11. COVID-19's effect on } \\
\text { your academics (i.e., } \\
\text { mandatory online classes) }\end{array}$ & $\begin{array}{l}152 \\
(3.1)\end{array}$ & $\begin{array}{l}729 \\
(14.7)\end{array}$ & $\begin{array}{l}1207 \\
(24.4)\end{array}$ & $\begin{array}{l}1343 \\
(27.1)\end{array}$ & $\begin{array}{l}1518 \\
(30.7)\end{array}$ & $\begin{array}{l}2.76 \\
(1.06)\end{array}$ \\
\hline $\begin{array}{l}\text { 12. COVID-19's effect on } \\
\text { your ability to graduate "on } \\
\text { time" }\end{array}$ & $\begin{array}{l}766 \\
(15.5)\end{array}$ & $\begin{array}{l}1474 \\
(29.8)\end{array}$ & $\begin{array}{l}1072 \\
(21.7)\end{array}$ & $\begin{array}{l}766 \\
(15.5)\end{array}$ & $\begin{array}{l}864 \\
(17.5)\end{array}$ & $\begin{array}{l}2.24 \\
(1.14)\end{array}$ \\
\hline $\begin{array}{l}\text { 13. COVID-19's effect on } \\
\text { your ability to obtain } \\
\text { employment after } \\
\text { graduating }\end{array}$ & $\begin{array}{l}782 \\
(15.8)\end{array}$ & $\begin{array}{l}1091 \\
(22.0)\end{array}$ & $\begin{array}{l}1085 \\
(21.9)\end{array}$ & $\begin{array}{l}907 \\
(18.3)\end{array}$ & $\begin{array}{l}1083 \\
(21.9)\end{array}$ & $\begin{array}{l}2.48 \\
(1.14)\end{array}$ \\
\hline
\end{tabular}




\begin{tabular}{|lllll|}
\hline Variable & & & $\mathbf{n}(\%)$ & \\
\hline COVID-19 Diagnosis History & Yes & No & Unsure & - \\
\hline $\begin{array}{l}\text { Personally contracted } \\
\text { COVID-19 }\end{array}$ & $31(0.6)$ & $\begin{array}{l}4719 \\
(95.9)\end{array}$ & $172(3.5)$ & - \\
\hline $\begin{array}{l}\text { Friend/family member } \\
\text { contracted COVID-19 }\end{array}$ & 791 & 3976 & $184(3.7)$ & \\
\hline
\end{tabular}

protocols $(X=1.87, S D=0.91)$ and the effect of the pandemic on their living situation $(X=1.98, S D=$ 1.04). Of those who provided an answer to questions about their COVID-19 mental illness diagnosis

history, $0.6 \%$ of the sample ( $n=31$ ) reported that they had personally contracted the virus, while $16 \%$ ( $n=$ 791) reported that either a friend or family member had.

Descriptive statistics for the mental health variables are presented in Table 3. The average resilience score for the sample was 26.20 ( $S D=6.32$ ), indicating a moderate level of resilience, which is consistent with the scale average observed in other Canadian student populations (30). The average psychological distress score for the sample was 28.67 ( $S D=9.53$ ). Based on the recommended cut points for scores indicative of likely experiencing a mental disorder, $17.8 \%, 18.0 \%$, and $45.0 \%$ of the sample were likely to have a mild, moderate, and severe mental disorder, respectively. Only $19.2 \%$ of the sample scored low enough on the K10 to suggest they were "likely to be well" ( $n=951)$. Finally, $30.8 \%$ of the sample ( $n=$ 1483) reported having a pre-existing, diagnosed mental illness.

Table 3

Descriptive Statistics for Mental Health Variables

\begin{tabular}{|lll|}
\hline Mental Health Variables & $\mathbf{n}(\%)$ & Mean (SD) \\
\hline Psychological distress (K10) & & $28.67(9.53)$ \\
\hline Likely to be well (score 10-19) & $951(19.2)$ & \\
\hline Mild disorder (score 20-24) & $879(17.8)$ & \\
\hline Moderate disorder (score 25-29) & $892(18.0)$ & $26.20(6.32)$ \\
\hline Severe disorder (score 30-50) & $2227(45.0)$ & \\
\hline Resilience (CD-RISC-10) & & \\
\hline Low resilience (score $\leq 26)$ & $2543(51.4)$ & \\
\hline High resilience (score >26) & $2407(48.6)$ \\
\hline
\end{tabular}

Note. ${ }^{1}$ Categories correspond to recommended cut points for scores on the K10 indicative of 
"likely mental disorder". Total K10 scale score ranges from 10-50.

2 Total CD-RISC-10 scale score ranges from 0-40.

Multivariable Analyses

As expected, resilience was found to be an effect modifier of the relationship between COVID-19 related stressors and psychological distress (Appendix B). As such, we stratified our sample by high and low resilience.

All COVID-19 related stressors were significantly associated with an increase in the likelihood of screening positive for at least a moderate mental disorder. Table 4 displays the results for adjusted and unadjusted models. Within the low resilience stratum, the strongest associations were observed for the following stressors: COVID-19's effect on my academics (RR=1.14 [95\% $\mathrm{Cl} 1.08,1.20]$ ); difficulties accessing mental/physical health care during the pandemic (RR=1.12 [95\% $\mathrm{Cl} 1.07,1.18])$; and loneliness as a result of quarantine/self-isolation $(R=1.11[95 \% \mathrm{Cl} 1.06,1.16])$. Within the high resilience stratum, the strongest associations were observed for: COVID-19's effect on my academics (RR=1.32 [95\% $\mathrm{Cl} 1.25$, 1.41]); difficulties accessing mental/physical healthcare during the pandemic ( $R R=1.25$ [95\% $\mathrm{Cl} 1.18$, 1.33])); and uncertainty around how long the pandemic will last ( $R R=1.24[95 \% \mathrm{Cl} 1.16,1.32])$. Overall, larger effects were observed for those in the high resilience stratum compared to those in the low resilience stratum. 
Table 4

Unadjusted and adjusted models for relationship between COVID-19 stressor variables and positive K10 screen for at least a moderate mental disorder, stratified by level of resilience

LOW RESILIENCE

HIGH

RESILIENCE

Stressor

Uncertainty around how long the pandemic

will last

Loneliness as a result of quarantine/self-

isolation

Worrying a family member/friend will

contract COVID-19

Worrying that I will contract COVID-19

Returning to school during COVID-19

COVID-19's effect on my

employment/finances

Difficulties accessing physical/mental health

care as a result of COVID-19

COVID-19's effect on your living situation

Ensuring I am effectively following COVID-19

safety protocols

People around me not effectively following

COVID-19 safety protocols
Unadjusted

RR $(95 \%$

Cl)

$1.12(1.06$,

1.17)

$1.13(1.08$

1.18)

$1.08(1.03$

1.13)

(1)

$1.06(1.02$

1.11)
Adjusted ${ }^{1} \quad$ Unadjusted

RR $(95 \%$
Cl)

$(1.04$

1.16)

1.11

$(1.06$,

1.16)

1.07

(1.02,

1.12)

1.05

(1.01,

1.10)

1.09 (1.05, $\quad 1.08$

1.15)

(1.03,

1.13)

1.10

$1.10(1.06$,

1.15)

(1.05,

1.15)

1.14 (1.09,

1.19)

1.12

(1.07,

1.18)

$1.09(1.05$,

1.14)

1.10

(1.05,

1.15)

$1.10(1.05$,

1.15)

1.09

(1.04,

1.14)

1.09 (1.04,

1.14)
1.07

(1.02,

1.12)
RR (95\%

Cl)

1.30 (1.23,

1.38)

$1.29(1.23$,

1.37)

1.20 (1.14,

1.27)

1.17 (1.10,

1.23)

1.24 (1.17,

1.31)

Adjusted $^{1}$

RR $(95 \%$

Cl)

1.24

(1.16,

1.32)

1.23

(1.16,

1.31)

1.16

(1.10,

1.23)

1.12

(1.06,

1.19)

1.18

(1.11,

1.25)

$1.26(1.19, \quad 1.22$

1.33)

(1.15,

1.29)

1.34 (1.27,

1.42)

1.25

(1.18,

1.33)

1.20

(1.13,

1.28)

$1.25(1.18$

1.33)

1.20

$(1.13$

1.28)

1.14

(1.07,

1.21)

Notes. (1) Models adjusted for the effects of: age, sex level of study, international student status, first generation student status, region of institution, and friend/family member COVID-19 diagnosis, and personal diagnosed mental illness. (2) Low resilience group defined as those who scored below the mean for the sample (score $\leq 26$ ), high resilience group defined as those who scored at the mean or higher (score >26). (3) Top three largest associations in adjusted models are bolded. 
COVID-19's effect on your academics (i.e., mandatory online classes)

COVID-19's effect on your ability to graduate "on time"

COVID-19's effect on your ability to obtain employment after graduating
1.15 (1.10,

1.21)
1.14

(1.08,

1.20)
$1.10(1.06$

1.15)

1.10

$(1.05$

1.15)

$1.07(1.03$

1.12)
1.08

$(1.03$

1.13)
1.39 (1.31,

1.47)

1.32

(1.25,

1.41)

1.21

(1.15,

1.28)

1.24 (1.18,

1.31)

1.23 (1.16,

1.29)

1.21

(1.15,

1.28)

Notes. (1) Models adjusted for the effects of: age, sex level of study, international student status, first generation student status, region of institution, and friend/family member COVID-19 diagnosis, and personal diagnosed mental illness. (2) Low resilience group defined as those who scored below the mean for the sample (score $\leq 26)$, high resilience group defined as those who scored at the mean or higher (score >26). (3) Top three largest associations in adjusted models are bolded.

\section{Discussion}

Although a handful of studies $(12,31-33)$ have investigated the relationship between pandemic-related stressors and student mental health, this study is the first to our knowledge to examine this association within a nation-wide sample of Canadian students. Consistent with previous work (12,31), our findings suggest that the COVID-19 pandemic has negatively impacted academics, physical and mental health, and lifestyle. In this study, the highest rated COVID-19 related stressors were: (1) uncertainty around the timeline of the pandemic (i.e., how long it would last for); (2) concerns about the effect of the pandemic on academics (e.g., classes switching to online format); (3) concerns around friends and/or family members contracting the virus; (4) loneliness as a result of quarantine and/or self-isolation; and (5) concerns about others not following safety protocols.

It is noteworthy that scores on the psychological distress scale used in this study were high on average, with $45 \%$ of the sample scoring high enough to meet the threshold for "severe" psychological distress. In contrast, less than $20 \%$ scored low enough on the scale to be "likely to be well". This is perhaps unsurprising, given that population-based cross-sectional data collected by Mental Health Research Canada during the same time frame as this study revealed that levels of self-reported anxiety and depression had tripled among young adults (34). The average resilience score for this sample was consistent with what has been observed in other studies conducted among North American university students (35-37). As expected, level of resilience was an effect modifier of the relationship between COVID-19 related stressors and psychological distress.

In this study, the largest relative risks were observed among the high resilience group, suggesting that the association between these stressors and the likelihood of screening positive for at least a moderate mental disorder was stronger among those students who self-reported a high level of resilience compared to those who reported low resilience. This finding was contrary to both our expectations and the well- 
established positive association between resilience and mental health $(38,39)$. One potential explanation for this pattern of findings lies in the complex definition of resilience, which is often context-dependent. Kaye-Kauderer and colleagues emphasized the complexity of the concept of resilience, particularly in the face of the COVID-19 pandemic (40). In the context of natural disasters - perhaps the closest allegory to the unprecedented global pandemic - scholars have suggested that resilience is composed of three main elements: control (the ability to manage and change our circumstances), coherence (the drive to know and understand circumstances, and the desire to remove uncertainty), and connectedness (having social supports to rely upon during times of upheaval) (41).

While we would typically expect to see high levels of all three of these psychological elements available to more resilient individuals, the pandemic impaired the ability to satisfy these psychological needs. In fact, stressors with the strongest associations with psychological distress in this study mapped to each of these elements, including worrying about the pandemic's effect on academics, graduation, and future employment (control), uncertainty around the length of the pandemic (coherence), and loneliness due to self-isolation and a reduced ability to access healthcare supports (connectedness). It is possible that more resilient individuals experienced slightly greater psychological distress from pandemic-related stressors as a result of being unable to access the usual supports they had grown to depend upon in the face of stress. In contrast, those with lower levels of resilience, for whom these elements are not typically satisfied in normal contexts, experienced a lesser overall impact.

\section{Limitations}

Findings from this study should be interpreted in light of the following limitations. First, sampling methods varied at each participating institution, which may have introduced sampling bias. The directionality of this bias is difficult to discern - either students with better mental health were more likely to participate or students with worse mental health were more inclined to participate. Consequently, our findings may under or overestimate the true impact of COVID-19 related stressors on students' psychological distress. Secondly, in response to the COVID-19 pandemic, prospective students may have elected to defer their university education. Data from a large, cross-sectional survey indicated that approximately $20 \%$ of American students reported that they were highly likely to defer their university studies (42). Given that students who elected to defer during the 2020-2021 academic year were not included in our sample, the generalizability of these findings may be limited. An intriguing question for future research may be whether pandemic-related stressors and psychological distress differ between students who chose to continue their education versus those who chose to defer during the pandemic.

Finally, it is important to note that the present study did not collect any information related to race or ethnicity. Research has consistently demonstrated that individuals from racial/ethnic minority groups are at an increased risk for developing mental disorders compared to their White counterparts $(43,44)$. In line with these findings, preliminary research also suggests that individuals from racial/ethnic minority groups may be differentially impacted in the COVID-19 pandemic and may suffer worse mental health outcomes $(33,45)$. Therefore, it is integral for subsequent examinations of student mental health during 
the pandemic to include data on these individuals and examine unique predictors of psychological distress and well-being in these students. The current study also utilized a cross-sectional design, which prevented us from drawing conclusions regarding causality between study variables. Future research should explore longitudinal data to evaluate the impact of the pandemic on university students' mental health over time.

\section{Conclusion}

Previous research has established a high prevalence of psychological distress among university students $(7,8,13,46)$. The COVID-19 pandemic introduced unprecedented disruptions to student mental health including a forced transition to virtual learning, increased social isolation and loneliness, concerns around fulfilling education requirements and securing employment following graduation, financial strain, and reduced access to mental health resources $(3,4,12)$. These challenges, in addition to pre-existing stressors, have exacerbated a longstanding public health concern, prompting calls for timely research examining the impact of COVID-19 related stressors on particular domains of student mental health (47).

Findings from this study demonstrated that loneliness, difficulties accessing healthcare, and concerns about academic performance were the most impacted areas of well-being among a nation-wide sample of Canadian university students. While the Public Health Agency of Canada has developed pandemic response guidelines for university institutions, these only briefly touch on the importance of addressing the psychosocial and mental health needs of students, faculty, and staff, and highlight general resources for mental health and substance use concerns (48). This is problematic considering the most prevalent pandemic-related stress experienced by Canadian students is related to feelings of isolation and difficulties navigating healthcare services. While it is acknowledged within these recommendations that university institutions should promote access to mental health support services and resources, these guidelines do not offer concrete instruction to these institutions on how to facilitate access to these supports (48). Our findings suggest a need for clear avenues for mental health supports and services to be made available to support university student well-being during the pandemic and its fallout.

The current study has identified several key areas of university student well-being that have been negatively impacted by the COVID-19 pandemic. In particular, feelings of loneliness stemming from social isolation, difficulties accessing healthcare, and concern regarding academics have been found to increase vulnerability for psychological distress among students. Moving forward it will be important for universities to adequately consider the importance of mental health supports and learning environments during the pandemic in order to effectively support student well-being. Addressing the aforementioned areas is necessary to alleviate the mental health burden experienced by university students as a result of the pandemic and its fallout.

\section{Abbreviations}

COVID-19 Severe Acute Respiratory Syndrome Coronavirus 2 
NCHA II National College Health Assessment II Survey

PSSI Post-Secondary Student Stressors Index

K10 Kessler Psychological Distress Scale

PSS10 Perceived Stress Scale

CD-RISC-10 Connor-Davidson Resiliecny Scale

\section{Declarations}

\section{Ethics approval and consent to participate}

Ethics approval was obtained from Queen's University's Health Sciences and Affiliated Teaching Hospitals Research Ethics Board (\#6029173) as the lead university, as well as from an ethics board at each participating university. Participants provided their free and informed consent to participate by indicating that they had read the Study Letter of Information and agreed to participate in the study prior to accessing the survey. All methods were performed in accordance with the relevant guidelines and regulations.

\section{Consent for publication}

Not applicable.

\section{Availability of data and materials}

The datasets generated and/or analysed during the current study are not publicly available due to REB restrictions but are available from the corresponding author on reasonable request.

\section{Competing Interests}

Dr. Brooke Linden is the creator of the Post-Secondary Student Stressors Index, one of the tools used in this study. This is a non-financial competing interest. All other authors have no conflicts of interest to disclose.

\section{Author's Contributions}

BL was the primary investigator of this project, and took a lead role in the analysis, interpretation, and writing of the manuscript. CM, SZ developed the conceptual idea for the study, and actively contributed to interpretation and writing and reviewing of the manuscript. JR provided support with the analysis and interpretation of the results, and contributed to the writing and reviewing of the manuscript. AM provided invaluable support to the conceptualization, analysis, and interpretation of the results, in addition to contributing to the writing and reviewing of the manuscript. All authors have reviewed and approved the final version of the manuscript. 
Acknowledgements

The authors have no acknowledgements to include.

\section{Author's Information}

Dr. Brooke Linden is a Research Scientist with the Health Services and Policy Research Institute at Queen's Univeristy. Caitlin Monaghan is a medical student at the University of Toronto. Sally Zheng is a graduate student in Clinical Psychology at Ryerson University. Jake Rose is a medical student at McGill University. Dr. Alyson Mahar is an Assistant Professor at the University of Manitoba.

\section{Funding}

This research did not receive any specific grant from funding agencies in the public, commercial, or notfor-profit sectors.

\section{References}

1. Mental Health Research Canada, Pollara Strategic Insights. Mental Health During COVID-19 Outbreak: Poll \#4 of 13 in a Series (Mid-December Data Collection). 2020.

2. Centre for Addiction and Mental Health. Anxiety patterns in Canadians mirror progression of pandemic [Internet]. 2020 [cited 2021 Jan 24]. Available from: https://www.camh.ca/en/camh-newsand-stories/anxiety-patterns-in-canadians-mirror-progression-of-pandemic

3. Sahu P. Closure of Universities Due to Coronavirus Disease 2019 (COVID-19): Impact on Education and Mental Health of Students and Academic Staff. Cureus [Internet]. 2020 Apr 4 [cited 2021 Jan 28];12(4). Available from: https://www.cureus.com/articles/30110-closure-of-universities-due-tocoronavirus-disease-2019-covid-19-impact-on-education-and-mental-health-of-students-andacademic-staff. doi:ï» ¿10.7759/cureus.7541

4. Lee J. Mental health effects of school closures during COVID-19. Lancet Child Adolesc Heal [Internet]. 2020 Jun 1 [cited 2021 Jan 28];4(6):421. Available from: . doi:10.1016/S23524642(20)30109-7

5. Statistics Canada. How are postsecondary students in Canada impacted by the COVID-19 pandemic? [Internet]. 2020 [cited 2021 Jan 28]. Available from: https://www150.statcan.gc.ca/n1/pub/11-627-m/11-627-m2020032-eng.htm

6. Linden B, Boyes R, Stuart H. The Post-Secondary Student Stressors Index: Proof of concept and implications for use. J Am Coll Heal. 2020. doi:10.1080/07448481.2020.1754222

7. American College Health Association. American College Health Association - National College Health Assessment II: Canadian Reference Group Data Report Spring 2019. Silver Spring, MD; 2019.

8. Robinson AM, Jubenville TM, Renny K, Cairns SL. Academic and mental health needs of students on a Canadian campus. Can J Couns Psychother. 2016;50(2):108-23. 
9. Arnett JJ. Emerging Adulthood A Theory of Development From the Late Teens Through the Twenties. Am Psych [Internet]. 2000 [cited 2021 Jan 17];55(5):469-80. Available from: http://jeffreyarnett.com/ARNETT_Emerging_Adulthood_theory.pdf. doi:10.1037/0003-066X.55.5.469

10. American Psychological Association. Building your resilience [Internet]. https://www.apa.org. 2021. Available from: https://www.apa.org/topics/resilience

11. Taylor SE, Stanton AL. Coping Resources, Coping Processes, and Mental Health. Annu Rev Clin Psychol [Internet]. 2007;(3):377-401. Available from: http://clinpsy.annualreviews.org. doi: 10.1146/annurev.clinpsy.3.022806.091520

12. Son C, Hegde S, Smith A, Wang X, Sasangohar F. Effects of COVID-19 on college students' mental health in the United States: Interview survey study [Internet]. Vol. 22, Journal of Medical Internet Research. JMIR Publications Inc.; 2020 [cited 2021 Jan 28]. Available from: /pmc/articles/PMC7473764/?report=abstract. doi:10.2196/21279

13. Auerbach RP, Alonso J, Axinn WG, Cuijpers P, Ebert DD, Green JG, et al. Mental disorders among college students in the World Health Organization World Mental Health Surveys [Internet]. Vol. 46, Psychological Medicine. Cambridge University Press; 2016 [cited 2021 Jan 28]. p. 2955-70. Available from: /pmc/articles/PMC5129654/?report=abstract. doi:10.1017/S0033291716001665

14. Monaghan C, Linden B, Stuart H. Postsecondary Mental Health Policy in Canada: A Scoping Review of the Grey Literature: Politique de santé mentale post-secondaire au Canada: un examen de la portée de la littérature grise. Can J Psychiatry [Internet]. 2020 Oct 5 [cited 2021 Jan 23];070674372096173. Available from: http://journals.sagepub.com/doi/10.1177/0706743720961733. doi:10.1177/0706743720961733

15. Linden B, Boyes R, Stuart H. Cross-Sectional Trend Analysis of the NCHA II Survey Data on Canadian Post- Secondary Student Mental Health and Wellbeing from 2013 to 2019. OSF Pre-print [Internet]. 2021;1-13. Available from: https://osf.io/gv4ex. doi:10.2196/27713

16. MacKean G. Mental health and well-being in post-secondary education settings: a literature and environmental scan to support planning and action in Canada. 2011.

17. Browning MHEM, Larson LR, Sharaievska I, Rigolon A, McAnirlin O, Mullenbach L, et al. Psychological impacts from COVID-19 among university students: Risk factors across seven states in the United States. PLoS One. 2021;16(1):e0245327. doi: ï» ¿ 10.1371/JOURNAL.PONE.0245327

18. Hamza CA, Ewing L, Heath NL, Goldstein AL. When social isolation is nothing new: A longitudinal study on psychological distress during COVID-19 among university students with and without preexisting mental health concerns. Can Psychol. 2021;62(1):20-30. doi: 10.1037/cap0000255

19. Linden B. Cross-Canada Release of the Post-Secondary Student Stressors Index (PSSI): Protocol for a Cross-sectional, Repeated Measures Study. JMIR Res Protoc 2021;10(8)e27713 https//www.researchprotocols.org/2021/8/e27713 [Internet]. 2021 Aug 31 [cited 2021 Sep 29];10(8):e27713. Available from: https://www.researchprotocols.org/2021/8/e27713. doi: $10.2196 / 27713$ 
20. American College Health Association, The Healthy Minds Network. The Impact of COVID-19 on College Student Well-being [Internet]. 2020 Apr. Available from: https://www.acha.org/documents/ncha/Healthy-Minds_NCHA_COVID-19_Survey_Report.pdf

21. Mental Health Research Canada, Pollara Strategic Insights. Mental Health During COVID-19 Outbreak Wave 1. Toronto; 2020 Apr.

22. Kessler R, Andrews G, Colpe LJ, Hiripi E, Mroczek DK, Normand S-LT, et al. Short screening scales to monitor population prevalences and trends in non-specific psychological distress. Psychol Med. 2002;32(6):959-76. doi:10.1017/S0033291702006074

23. Campbell-Sills $L$, Stein MB. Psychometric analysis and refinement of the Connor-Davidson Resilience Scale (CD-RISC): Validation of a 10-item measure of resilience. J Trauma Stress. 2007;20(6):1019-28. doi:ï»¿10.1002/jts.20271

24. Smith KJ, Emerson DJ, Haight TD, Mauldin S, Wood BG. An examination of the psychometric properties of the Connor-Davidson Resilience Scale-10 (CD-RISC10) among accounting and business students. 2019 [cited 2021 Aug 17]; Available from: https://doi.org/10.1016/j.jaccedu.2019.01.002

25. Linden B, Stuart H. Psychometric assessment of the Post- Secondary Student Stressors Index (PSSI). BMC Public Heal 2019191 [Internet]. 2019 Aug 19 [cited 2021 Aug 17];19(1):1-12. Available from: https://bmcpublichealth.biomedcentral.com/articles/10.1186/s12889-019-7472-z. doi:ï»¿10.1186/s12889-019-7472-z

26. Hébert M, Parent N, Simard C, Laverdière A. Validation of the French Canadian version of the brief Connor-Davidson resilience scale (CD-RISC 10). Can J Behav Sci. 2018;50(1):9-16. doi: $10.1037 / \mathrm{cbs} 0000092$

27. Stallman HM. Psychological distress in university students: A comparison with general population data. Aust Psychol. 2010;45(4):249-57. doi:10.1080/00050067.2010.482109

28. National Standard for Health Assessment of Rail Safety Workers. The Kessler Psychological Distress Scale (K10) [Internet]. 2006 [cited 2021 Sep 29]. Available from: http://www.scalesandmeasures.net/files/files/Kessler (K10) 1992.pdf

29. Gallis JA, Turner EL. Relative measures of association for binary outcomes: Challenges and recommendations for the global health researcher. Ann Glob Heal. 2019;85(1):1-12. doi: 10.5334/aogh. 2581

30. Davidson J. Connor-Davidson Resilience Scale (CD-RISC) Manual. Unpublished. 08-19-2018. [cited 2021 Aug 17]; Available from: www.cdrisc.com

31. Cao W, Fang Z, Hou G, Han M, Xu X, Dong J, et al. The psychological impact of the COVID-19 epidemic on college students in China. Psychiatry Res [Internet]. 2020 May 16;287:112934. Available from: https://www.sciencedirect.com/science/article/pii/S0165178120305400. doi: 10.1371/JOURNAL.PONE.0245327

32. Copeland WE, McGinnis E, Bai Y, Adams Z, Nardone H, Devadanam V, et al. Impact of COVID-19 Pandemic on College Student Mental Health and Wellness. J Am Acad Child Adolesc Psychiatry 
[Internet]. 2021 May 16;60(1):134-141.e2. Available from:

https://www.sciencedirect.com/science/article/pii/S0890856720319882

33. Zimmermann M, Bledsoe C, Papa A. The Impact of the COVID-19 Pandemic on College Student Mental Health: A Longitudinal Examination of Risk and Protective Factors [Internet]. PsyArXiv; 2020 May. Available from: https://psyarxiv.com/2y7hu/. ï»¿doi:10.31234/osf.io/2y7hu

34. Mental Health Research Canada, Pollara Insights. Mental Health During COVID-19 Outbreak: Poll \#3 [Internet]. 2020 [cited 2021 Jan 24]. Available from: https://www.mhrc.ca/national-pollcovid/findings-of-poll-3

35. Shlomi H. The Relationship between Childhood Family Instability, Secure Attachment, and the Sense of Belonging of Young Adults [Internet]. 2010. Available from:

https://open.library.ubc.ca/soa/clRcle/collections/undergraduateresearch/52966/items/1.0086035 doi:10.14288/1.0086035

36. Campbell-Sills L, Roy-Byrne PP, Craske MG, Bystritsky A, Sullivan G, Stein MB. Improving outcomes for patients with medication-resistant anxiety: effects of collaborative care with cognitive behavioral therapy. Depress Anxiety [Internet]. 2016;33(12):1099-106. Available from:

http://ovidsp.ovid.com/ovidweb.cgi?

$T=J S \& C S C=Y \& N E W S=N \& P A G E=$ fulltext\&D=emed17\&AN $=613341620$

http://bf4dv7zn3u.search.serialssolutions.com.myaccess.library.utoronto.ca/?url_ver=Z39.882004\&rft_val_fmt=info:ofi/fmt:kev:mtx:journal\&rfr_id=info:sid/Ovid:emed17\&r.

doi:10.1002/da.22574

37. Rahimi B, Baetz M, Bowen R, Balbuena L. Canadian Medical Education Journal Resilience, stress, and coping among Canadian medical students [Internet]. Vol. 5, Canadian Medical Education Journal. 2014. Available from: http://www.cmej.ca

38. Davydov DM, Stewart R, Ritchie K, Chaudieu I. Resilience and mental health. Clin Psychol Rev. 2010; (30):479-95. doi:ï» ¿10.1016/j.cpr.2010.03.003

39. Hu T, Zhang D, Wang J. A meta-analysis of the trait resilience and mental health. Pers Individ Dif [Internet]. 2015 May 16;76:18-27. Available from:

https://www.sciencedirect.com/science/article/pii/S0191886914006710. doi:

10.1016/j.paid.2014.11.039

40. Kaye-Kauderer H, Feingold JH, Feder A, Southwick S, Charney D. Resilience in the age of COVID-19. Available from: https://www.cambridge.org/core.

41. Reich JW. Three psychological principles of resilience in natural disasters. Disaster Prev Manag An Int J. 2006;15(5):793-8. doi:10.1108/09653560610712739

42. Simpson Scarborough. Higher Ed and COVID-19 National Student Survey [Internet]. 2020. Available from: https://cdn2.hubspot.net/hubfs/4254080/SimpsonScarborough National Student Survey.pdf

43. Breslau J, Aguilar-Gaxiola S, Kendler KS, Su M, Williams D, Kessler RC. Specifying race-ethnic differences in risk for psychiatric disorder in a USA national sample. Psychol Med [Internet]. 
2006;36(1):57-68. Available from: https://europepmc.org/articles/pmc1924605?pdf=render. doi: 10.1108/09653560610712739

44. Breslau J, Kendler KS, Su M, Gaxiola-Aguilar S, Kessler RC. Lifetime risk and persistence of psychiatric disorders across ethnic groups in the United States. Psychol Med [Internet]. 2005;35(3):317-27. Available from: https://europepmc.org/articles/pmc2748985?pdf=render. doi: $10.1017 / \mathrm{s} 0033291704003514$

45. Proto E, Quintana-Domeque C. COVID-19 and mental health deterioration by ethnicity and gender in the UK. PLoS One [Internet]. 2021 May 15;16(1):e0244419. Available from:

https://journals. plos.org/plosone/article?id=10.1371/journal.pone.0244419. doi:ï» ¿10.1371/journal.pone.0244419

46. Duffy A, Keown-Stoneman C, Goodday S, Horrocks J, Lowe M, King N, et al. Predictors of mental health and academic outcomes in first-year university students: Identifying prevention and earlyintervention targets. BJPsych Open [Internet]. 2020 May 15;6(3):e46. Available from: https://www.cambridge.org/core/product/identifier/S2056472420000241/type/journal_article. doi: 10.1192/bjo.2020.24

47. Grubic N, Badovinac S, Johri AM. Student mental health in the midst of the COVID-19 pandemic: A call for further research and immediate solutions. Int J Soc Psychiatry [Internet]. 2020 May 15;66(5):517-8. Available from: https://doi.org/10.1177/0020764020925108

48. Government of Canada. Guidance for post-secondary institutions during the COVID-19 pandemic [Internet]. 2020 [cited 2021 Jan 26]. Available from: https://www.canada.ca/en/publichealth/services/diseases/2019-novel-coronavirus-infection/guidance-documents/covid-19-guidancepost-secondary-institutions-during-pandemic.html

\section{Supplementary Files}

This is a list of supplementary files associated with this preprint. Click to download.

- AppendixA.docx

- AppendixB.docx 